\title{
The Science of Religion, Folklore Studies, and the Occult Field in Great Britain (1870-1914): Some Observations on Competition and Cain-Abel Conflicts
}

\begin{abstract}
The emergence of Religious Studies, or "the science of religion", as it used to be called in Great Britain, in the late 19th century is accompanied by a competition with other discourses interpreting religion. The present article (abridgment of a longer study) analyses the social and cultural place of Victorian and Edwardian Religious Studies as a project only partially existing in a University context, but mainly in learned societies, as the Folklore Society, and promulgated by scholars with a predominantly non-theological background. As such Religious Studies were both influenced by and competing with occult and esoteric groups interpreting religion and searching for a basic unity of religions as first of all the Theosophical Society, but also by and with other groups.
\end{abstract}

\section{The Emergence of a New Science of Religion in Great Britain: Introductory Remarks}

How do new sciences come into being? "We are all, we who work at these topics, engaged in science, the science of man, or rather we are painfully labouring to lay the foundations of that science“, Andrew Lang says in the same year that Queen Victoria died. ${ }^{2}$ Now the Scottish writer Andrew Lang (1844-1912) during his lifetime had been a perhaps even more well-known scholar of folklore, folktales, magic, religion and tradition in a more general way than even Sir James George Frazer (1854-1941) who today is most often seen as the acme of late Victorian and Edwardian scholarship on these subjects, both being Scotsmen and late descendants of Scottish Enlichtenment, as it happens. Both had also been (in a respectful way) opponents, and both embody the different poles of scholarship on religion in late Victorian England.

\footnotetext{
1 This is a very much abridged version of a study which for space constraints could not be published in this volume, with most documentation left out, which should appear at some other occasion.
}

2 Andrew Lang, Magic and Religion (London: Longmans, Green, and Co., 1901), 9.

Ә Open Access. (C) 2021 Marco Frenschkowski, published by De Gruyter. (cc) BY-NC-ND This work is licensed under a Creative Commons Attribution-NonCommercial-NoDerivatives 4.0 International License. 
The Victorian and Edwardian Ages in Great Britain have seen the birth of quite a number of new scientific approaches, culminating of course in Darwinism that quickly changed so many outlooks and created a new profile of the whole age. Edward Clodd (1840-1930), a scholar on the anthropological lines of E. B. Tylor, biographer of Charles Darwin, Thomas Huxley and Herbert Spencer, wrote in 1891:

Thus, the study of myth is nothing less than the study of the mental and spiritual history of mankind. It is a branch of that larger, vaster science of evolution which so occupies our thoughts to-day [. . .]. The evidence which it brings from the living and dead mythologies of every race is in accord with that furnished by their more tangible relics, that the history of mankind is a history of slow but sure advance from a lower to a higher; of ascent, although with oft backslidings. It confirms a momentous canon of modern science, that the laws of evolution in the spiritual world are as determinable as they are in the physical. [. . .] With the theory of evolution in our hands as the master-key, the immense array of facts that seemed to lie unrelated and discrete are seen to be interrelated and in necessary dependence. ${ }^{3}$

This is a telling passage, expressed by a scholar both deeply sceptical about religion and deeply interested in it, as might also be said about Frazer. Evolution became a basic paradigm: for biology as for cultural anthropology, for history and philosophy, for religion as well as - we may add - for occultism and other forms of rejected knowledge (to use the term of James Webb ${ }^{4}$ ).

During the second half of the nineteenth century the colonial age had reached a critical stage. British society realized that at least some of the countries which were part of the Empire did not simply exhibit inferior cultures, and especially India had as much to give as it had to take from Europe. The drive to re-organize the world according to British standards also allowed for a new fascination with the sheer otherness of the cultures encountered. This colonial experience coincided with a new look at one's own cultural background. Traditional agrarian society perceived from an industrial and urban setting suddenly seemed as strange as a far-away foreign country. What soldiers, merchants, administrators and missionaries encountered in the colonial situation somehow gave a new meaning to their own folktales and folklore at home. This complex development contributed to the science of religion, defining its ideological background, and its deep connectedness to ethnology and folklore studies. A new science always will cover aspects of discovery as well as of conquest, of curiosity and of fascination, but also of taking possession, even of invading a

3 Edward Clodd, Myths and Dreams (London: Chatto \& Windus, 1891), 139.

4 James Webb, Die Flucht vor der Vernunft. Politik, Kultur und Okkultismus im 19. Jahrhundert, ed. Marco Frenschkowski and Michael Siefener, trans. Michael Siefener (Wiesbaden: Marixverlag, 2009). 
new area of knowledge. To express it in another way: a new science is the epistemological equivalent of colonialism. Does this apply also to Religious Studies, or the science of religion? And how does it relate to the tension between mainstream discourses and fringe discourses, between the basic epistemological identity of nineteenth century society and its alterity? I concentrate in the following remarks on Great Britain, and do not generally claim that the origin of Religious Studies (to use a rather neutral though more recent term) in France, Germany, the Netherlands, Japan or even in the USA can be described along the same lines.

"The antecedents of comparative religion were far more numerous, and far more diverse, than is commonly realised". 5 The "Science of Religion" can with some plausibility be said to have come into being in the 1860-1900 period. The term itself is a nineteenth century British creation coined first by Friedrich Max Müller in $1860 .^{6}$ Of course religion as a subject of comparative research has a long scholarly ancestry with names like Herodotus, Plutarch and Porphyry, al-Bīrūnī and aš-Šahrastānī, Nicolaus Cusanus, Alexander Ross, John Spencer and Charles François Dupuis. A large number of ethnographic, oriental and other scholars, travellers, colonial administration clerks and missionaries have contributed to this ancestry as well. These older writers very much discuss the diversity of religions, and seriously collect data, but they do not yet define a new science. What they have achieved is not the same as what Friedrich Max Müller (1823-1900), Sir Edward Burnett Tylor (1832-1917), Herbert Spencer (1820-1903), William Robertson Smith (1846-1894), Andrew Lang, Edwin Sidney Hartland (1848-1927), Jane Ellen Harrison (1850-1928), Sir J. G. Frazer and, as an American spending much time in Europe and a somewhat different thinker, William James (1842-1910) had tried to do. What these scholars had in view might be called a general theory of religion and its origins, analysed outside of Christian theological prerequisites. As such it was meant to become a reference frame of religious history (more or less according to an evolutionary paradigm) that allows for a general pattern on how religion develops, and what its changing place in culture might be. Comparative religion (a term coming into more general use in the early twentieth century) or history of religion were established as parts of anthropology, and, perhaps even more telling, in very close contact with folklore studies. With the exception of Spencer and James all scholars we mentioned strongly interact with folklore studies (or criticize it, as Müller): comparative religion and

5 Eric J. Sharpe, Comparative Religion: A History (La Salle, Illinois: Open Court, 1986), 1.

6 Cf. Louis Henry Jordan, Comparative Religion: Its Genesis and Growth. (Edinburgh: T. \& T. Clark, 1905), 25; Lourens van den Bosch, Friedrich Max Müller: A Life Devoted to the Humanities (Leiden: Brill, 2002), 294 n. 3. 
folklore studies are almost twin sisters, and their ways separated in Britain only slowly around WWI.

Historical linguistics with the Leipzig School of Neogrammarians had in the 1860s-1890s proven the strict regularity of sound changes, and by this had founded a science of language that could treat language and etymology on historical lines comparable to the natural sciences. Scholars like Müller who had a strong background in historical linguistics to some degree hoped for a science of religion that could meet on equal terms with such achievements. His interest had been originally in mythology and its origin. Like Charles François Dupuis (1742-1809), Adalbert Kuhn (1812-1881), George William Cox (1827-1902), Friedrich Leberecht Wilhelm Schwartz (1821-1899), Abram Smythe Palmer (1844-1917) and many others, he was fascinated by mythology as a possible poetic interpretation and expression of nature and its forces ("naturmythologische Schule"), but as is well known he also emphasized its possible origin in metaphorical language as such. ${ }^{7}$ With William Robertson Smith and his Lectures on the Religion of the Semites $(1889)^{8}$ ritual took its place next to mythology as something to be researched on comparative and historical lines as well. The term "comparative mythology" is much older than "comparative religion", used e.g. by Müller already in his “Comparative Mythology" of 1856, a study re-issued by his disciple Abraham Smythe Palmer with many annotations as late as 1908. Interestingly Müller himself saw the Moghul emperor Akbar (1542-1605) as the first person "who ventured on a comparative study of the religions of the world". 9

Earlier scholars of religions had been mostly theologians, or at least they moved in a reference frame defined by different Christian theologies of religion. This now changed rapidly, for quite different reasons. William Robinson Smith had been mobbed out of academic theology at Aberdeen Free Church College in 1881 (he became librarian in Cambridge, and later first Reader and then from 1889 on Professor of Arabic), as in Germany something similar happened a year later to Julius Wellhausen, greatest Old Testament scholar of his generation, when he had to resign his theological chair at the University of Greifswald. ${ }^{10}$ More importantly, scholars increasingly began researching religion who had no

7 Cf. Bosch, Friedrich Max Müller, 253-292.

8 William R. Smith, Lectures on the Religion of the Semites: Fundamental Institutions, 1st ser. (London: Adam \& Charles Black, 1889).

9 Friedrich Max Müller, Introduction to the Science of Religion: Four Lectures Delivered at the Royal Institution; With two Essays on False Analogies, and the Philosophy of Mythology (London: Longmans, Green and Co., 1873), 209.

10 Marco Frenschkowski, "Wellhausen, Julius," in Biographisch-Bibliographisches Kirchen Lexikon 13, ed. Friedrich Wilhelm Bautz (Hamm: Bautz, 1998), 716-727. 
theological background, had never worked in a church context and did not use a theological reference frame in their style of asking questions. F. M. Müller had been a German philologian of Indo-European languages specializing in Sanskrit, who was invited to work in Oxford and edit the Rig-Veda (being a foreigner, he did not become Boden Professor of Sanskrit, however). ${ }^{11}$ E. B. Tylor came from a wealthy family of Quakers who owned a London brass factory, a religious background which effectively prevented his gaining a University degree and an early academic career: he started his work by collecting ethnological data in Mexico. J. G. Frazer was initially a classical philologian (his commentaries on Ovid, Ps.Apollodor and Pausanias still are monuments of erudition), and he only slowly began to include ethnological material in his theories, after having read Tylor and having made the personal acquaintance of W. Robertson Smith (whom he regarded as the "greatest man he had ever known", as he told to his biographer R. Angus Downie), widening the horizon of classical studies in an unprecedented way. ${ }^{12}$ E. S. Hartland had made a career as a solicitor in Swansea (though his father was a congregational minister). Frazer's father also had wanted his son to enter the legal profession, and Frazer even qualified for the bar, though later he never practiced law. Hartland, who lived from this practice, turned from folklore scholarship to impressive comparative studies on religion, giving attention also to aspects of social history. (John Ferguson McLennan, 1827-1881, who preceded Hartland in his extensive studies on family and kinship structures in primitive religion, also by profession had been an advocate). Andrew Lang, son of a town clerk at Selkirk, had been a historian, literary critic, writer, editor of the most successful folktale collections of the Victorian age, a poet and general man of letters. Later he became an honorary fellow at Merton College, Oxford. In Religious Studies he was the main opponent of Frazer, though they had more in common than meets the eye at first glance. Other names might be mentioned as well (William James, born into a wealthy American family, interestingly had a different background, having been the son of a Swedenborgian preacher, Henry James Sr.). No one of these scholars we have in view had ever studied Christian theology as a regular study. Religion was very much a subject of public debate in Victorian society, however, and many non-theologians participated. Müller could even write, in the passages introducing his Sacred Books of the East, the most

\footnotetext{
11 His German roots made him suspect in the United Kingdom: "Von der deutschen Theologie sprach man wie von einer Art verbotener Frucht, die man weder ansehen, noch antasten, noch gar kosten dürfe" (Friedrich Max Müller, Aus meinem Leben: Fragmente zu einer Selbstbiographie (Gotha: Perthes, 1902), 244).

12 Cf. Emily Varto, ed., Brill's Companion to Classics and Early Anthropology (Leiden: Brill, 2018).
} 
enduring monument of Victorian scholarship on religion: "No doubt there exists at present a very keen interest in questions connected with the origin, the growth, and decay of religion". ${ }^{13}$ Even Thomas Huxley, Darwin's most successful and noted populariser, biologist and defender of rationalism, wrote extensively on religion. In the nine volumes of his Collected Essays (1893-1894) ${ }^{14}$ approximately a third of the studies touch on religious matters, and two full volumes are dedicated to "Science and Hebrew tradition" (i.e. the Pentateuch and other Old Testament matters) and "Science and Christian tradition", interpreting religion on evolutionary lines. About Huxley's standing as a public intellectual Andrew Lang could even write in 1894: "In England, when people say "science", they commonly mean an article by Professor Huxley in The Nineteenth Century". ${ }^{15}$

\section{The Science of Religion and Its Hidden Dialogue with Occultism}

This volume (and the conference it records) starts with the working hypothesis that occultism in a wide sense, encompassing spiritualism, theosophy and other forms of rejected and alternate knowledge, has a place in the early history of religious studies. What exactly this place might have been remains to be figured out. If we cast our net too wide, we will not be able to get past vague impressions and general ideas about possible influences. This will lead exactly nowhere. But we can reasonably ask a number of relevant smaller questions that can possibly be answered, and might indeed help to get to a more nuanced image of the science of religion in its early days. Some of these smaller questions are: What can reasonably be said about common ideas and paradigms between the competing systems of interpretation? Do they have a common social and cultural background, to some degree? What about their networking? To what degree did the relevant people know (and perhaps respect) each other? To understand a new science it is not enough to take a close look at its intellectual world, and it is not enough to read its books, but we have to look at the scholars

13 Friedrich Max Müller, The Upanishads I, The Sacred Books of the East 1 (Oxford: Clarendon, 1879), XLII.

14 Thomas Huxley, Collected Essays, 9 vols. (London: Macmillan and Co., 1893-1895).

15 Andrew Lang, The Edinburgh Critical Edition of the Selected Writings, ed. Andrew Teverson, Alexandra Warwick, and Leigh Wilson, vol 1, Anthropology: Fairy Tale, Folklore, the Origins of Religion, Psychical Research (Edinburgh: Edinburgh University Press, 2015), 268. 
who created it, their social and cultural background, their agendas, their careers, their desire for knowledge. What do we know about the personal hidden research agendas and belief systems of the relevant scholars? Do their letters and diaries make agendas visible that did not go into published studies? Tylor for example as a young man collected material on Spiritualism in which he never believed but which went into the ideas of Primitive Culture, ${ }^{16}$ his major and most influential work. Wouter Hanegraaff in a study published in 1998 put some emphasis on this point in his discussion of Tylor's views on magic, which for Tylor at first glance is essentially superstition. Hanegraaff makes plausible that both Tylor's and Frazer's views on magic "have their origin in the late fifteenth and early sixteenth century, although their backgrounds are ultimately rooted in antiquity". ${ }^{17}$ He demonstrates that categories and distinctions vital to both authors can be derived from writers as Agrippa, author of the most influential Renaissance treatise on magic. ${ }^{18}$ An 1872 notebook of Tylor documents his interest and deep researches in spiritualism, even attending spiritist séances in London. ${ }^{19}$ It is generally assumed he did not share any supernatural convictions, but this is not completely true: Tylor opens a crack in the door to occultism conceding there may be at least something in it:

My judgment is in abeyance. I admit a prima facie case on evidence, \& will not deny that there may be psychic forces causing raps, movements, levitations, etc. But it has not proved itself by evidence of my sense, and I distinctly think the case weaker than written documents led me to think. ${ }^{20}$

This is in some opposition to his attacks on superstition, and also clearly says his belief in the possibility of spiritualist phenomena to have been greater before he visited séances, i.e. when he wrote Primitive Culture. Even more interesting is the

16 Edward Burnett Tylor, Primitive Culture: Researches into the Development of Mythology, Philosophy, Religion, Language, Art, and Custom, vol. 1, 6th ed. (London: John Murray, 1920) 141-143.

17 Wouter J. Hanegraaff, "The Emergence of the Academic Science of Magic: The Occult Philosophy in Tylor and Frazer," in Religion in the Making: The Emergence of the Sciences of Religion, ed. Arie L. Moldedijk et al. (Leiden: Brill, 1998), 254.

18 Hanegraaf, "Emergence of the Academic Science,” 266. Cf. Marco Frenschkowski, „Heinrich Cornelius Agrippa von Nettesheim und seine „Okkulte Philosophie“: Ein Vorwort,“ in Agrippa Heinrich Cornelius Agrippa von Nettesheim, Die magischen Werke und weitere Renaissancetraktate, ed. and introd. Marco Frenschkowski (Wiesbaden: Marixverlag, 2008), 23-45.

19 Published in: George W. Stocking, “Animism in Theory and Practice: E. B. Tylor's Unpublished Notes on Spiritualism," Man 6 (1971): 88-104.

20 Cited in Stocking, "Animism in Theory and Practice," 100. 
choice of subjects in his Magnum opus. Magic and witchcraft are omnipresent. ${ }^{21}$ Spiritualism, table-rapping, tales of possession are discussed as alleged survivals of primitive attitudes. ${ }^{22}$ Stories about levitation are treated at much more length than the argument requires: ${ }^{23}$ they clearly fascinated Tylor, as do the magical school of Salamanca, lycanthropy, incubi, demonology, vampires ${ }^{24}$ and of course more generally all kinds of mythology, which he sees as a savage occupation of a quintessentially childlike mind. ${ }^{25}$ This metaphor of magic and mythology as representing a "child phase" of human history is very common in Victorian ethnology. ${ }^{26}$ Though there are many other subjects included in his survey of "primitive culture", the prevalence of occult and magical matters is significant (Adolf Bastian and Jacob Grimm being among his main sources for details). Tylor virtually identifies magic with "occult science". ${ }^{27}$ Magic is "a contemptible superstition" and "one of the most pernicious delusions that ever vexed mankind". ${ }^{28}$ But his statements on the relation between religion and magic are contradictory, ${ }^{29}$ and a certain ambiguity between his judgements and his thematic preferences is observable.

Frazer used much more clear-cut terms, but the basic observation holds true for him also. Tylor's polemics against magic, and even more against ecstatic and visionary elements in religions ${ }^{30}$ have an element of warding off, of an exorcism against irrationalism. But his fascination with magic looms up again when we learn he privately and passionately collected charms and amulets: at the Second International Folk-Lore Congress which met at the Society of Antiquaries in London (Burlington House) in Oct. 1-7, 1891 Tylor even put his collection on public exhibition, commenting on the subject:

Though often written of, such objects are comparatively seldom seen so that it is still worthwhile to exhibit specimens of them to students of Folk-lore. [. . . ] I have for years

21 Tylor, Primitive Culture, vol. 1, 112-159; Tylor, Primitive Culture, vol. 2, 111-112. a.o.

22 Tylor, Primitive Culture, vol. 1, 141-148; cf. Tylor, Primitive Culture, vol. 2, 135 on exorcisms.

23 Tylor, Primitive Culture, vol. 1, 149-152.

24 Tylor, Primitive Culture, vol. 1, 85-86, 308-315; Tylor, Primitive Culture, vol. 2, 189-194 (vampires are also a favourite subject in theosophical literature).

25 Tylor, Primitive Culture, vol. 1, 31, 176, 237, 284, 304, 368, 484 a.o.

26 Cf. e.g. Edward Clodd, The Childhood of Religions: Embracing a Simple Account of the Birth and Growth of Myths and Legends (London: Henry S. King, 1875) passim; John Fiske, Myths and Myth-Makers: Old Tales and Superstitions Interpreted by Comparative Mythology (Boston: Houghton, Mifflin and Company; Cambridge: The Riverside Press, 1902), 295.

27 Tylor, Primitive Culture, vol. 1, 128-129.

28 Tylor, Primitive Culture, vol. 1, 112-113.

29 Noted already by Hanegraaff, “The Emergence of the Academic Science of Magic," 262-263.

30 Tylor, Primitive Culture, vol. 2, 49, 132, 182, 410, 415, 421 a.o. 
endeavoured to prove that the main source of Mythology is also the main source of Magic. Down from our own level to that of the peasant and the savage, the process of sympathetic magic is to be traced to the same intelligible, but illogical, association of ideas which lies at the root of the apparently creative fancies of the myth-maker. ${ }^{31}$

Leland, the witchcraft scholar, was present at the exhibition and added comments that have been printed also. Now and then Tylor polemicizes against modern occultism, as e.g. when writing on snake cults, that indeed were a subject of much interest to Victorian occultists. ${ }^{32}$ When dealing of the Fortunate Islands, he playfully elaborates on the idea Britain itself may be a kind of Island of the Dead, which may have led to its popular interest in ghosts. $^{33}$

We have asked whether we can discern subjects that fascinated the early scholars of religion, perhaps hinting at hidden backgrounds in their research agendas, subjects or ideas that turn up again and again making plausible some subtle and so to say subterraneous aspects not too obvious in the leading theoretical framework. It is not too difficult to find evidence in this quest.

Edwin Sidney Hartland e.g., who had adopted the legal profession and worked as a solicitor and in local politics, but also was keenly interested in folklore and anthropology, wrote one the most remarkable books of the 1890s on religion and myth, the three-volume monumental The Legend of Perseus. ${ }^{34}$ This indeed after The Golden Bough (first edition in two volumes 1890) has been the most influential book in the growing field between comparative religion, folklore studies and anthropology of the 1890s taking up Tylor's basic concepts and refining them, but it shared the fate of much pre-Frazerian works to fade in the light of Frazer's fame. Hartland still in the years around WWI wrote

31 Edward Burnett Tylor, "Exhibition of Charms and Amulets," in The International Folk-Lore Congress 1892: Papers and Transactions, ed. Joseph Jacobs, and Alfred Nutt (London: David Nutt, 1892), 387.

32 Tylor, Primitive Culture, vol. 2, 233-242, particularly 239. On Leland see Marco Frenschkowski, "Charles Godfrey Leland (1824-1903) und die Ursprünge der Wicca-Religion,“" in Faszination des Okkulten. Diskurse zum Übersinnlichen, ed. Wolfgang Müller-Funk and Christa Agnes Tuczay (Tübingen: Francke 2008), 273-335.

33 Tylor, Primitive Culture, vol. 2, 63-64. On the background of this idea cf. Marco Frenschkowski, "Fortunatae Insulae: Die Identifikation mythischer Inseln mit realen geographischen Gegebenheiten in der griechischen und römischen Antike,” in Konstruktionen mediterraner Insularitäten, ed. Reinhard von Bendemann et al. (Paderborn: Fink/Schöningh, 2016), 43-73.

34 Edwin S. Hartland, The Legend of Perseus: A Study of Tradition in Story, Custom, and Belief, 3 vols. (London: David Nutt, 1894-1896). 
important books in the field, as his Primitive Paternity. ${ }^{35}$ Volume two of his The Legend of Perseus discusses the idea of the external soul, much captivating the imagination of the Victorians (Oscar Wilde's 1890-1891 novel The Picture of Dorian Gray being a well-known example). The soul in this anthropological approach is not simply the soul of psychology: it is a mythical combination of life soul, breath, shadow, double, heavenly archetype, blood soul, external soul and life token, with other mental and magical aspects as well. Can we with some plausibility see in this fascination with darker and less obvious and archaic complexities of the soul a connection to the complex theosophical models of inner man?

The fascination with archaic and complex concepts of soul is one such example of a hidden agenda, the overwhelming and far-reaching obsession with magic, sorcery, taboo complexes is a very obvious other one. This has been observed before, of course: "Tylor and Frazer are pioneers in the "emergence of the scientific study of religion", but my analysis implies that their work could with equal theoretical justification be referred to as a "scientific study of magic", Wouter Hanegraaff wrote. ${ }^{36}$ Without exception all authors we have mentioned so far as scholars of religion in the years after Müller have extensively written on both European and non-European magic, perhaps more than on any other aspect of religion (though they usually saw magic in opposition to religion, a view since discredited). Indeed for the most emphatically rationalist writers of our group (Tylor and Frazer), it can plausibly be called their chosen main subject. On the level of public statements Frazer and Tylor were quite sceptical, seeing themselves in the tradition of Scottish enlightenment and rationalism with its pragmatic approach. And yet they spent their life researching magic. This observation curiously finds some kind of synchronicity in the renaissance of ceremonial magic in the Hermetic Order of the Golden Dawn founded in $1888^{37}$ and similar late nineteenth century by-ways of Victorian society. Ceremonial magic and scholarly fascination by magic are parallel stories not in any direct contact with each other (as far as we know), but they are equally connected to the spirit of the Victorian age as an aspect of its nonstandard and non-mainstream underground. "The relations of religion and

35 Edwin S. Hartland, Primitive Paternity: The Myth of Supernatural Birth in Relation to the History of the Family, 2 vols. (London: David Nutt, 1909-1910).

36 Hanegraaff, “The Emergence of the Academic Science of Magic," 272-273.

37 For literature and sources see Marco Frenschkowski, Die Geheimbünde: Eine kulturgeschichtliche Analyse, 6th ed. (Wiesbaden: Marixverlag, 2016). 
magic" ${ }^{38}$ in some sense is the one main subject matter of early British cultural anthropology, struggling to become part of the academic mainstream. Frazer, as already mentioned, originally called his Magnum opus, still the best-known of British books on primitive religion, The Golden Bough: A Study in Comparative Religion (1890 edition), but he retitled it The Golden Bough: A Study in Magic and Religion in its second and third edition (1900 and 1906-1937). ${ }^{39}$ Even the rationalist Edward Clodd, folklorist and friend of Frazer, was intrigued by ideas of magic words and their effectivity. His monograph Tom Tit Tot ${ }^{40}$ is still a classic presentation on "words of power", charms, conjurations and taboo words in folk tales. ${ }^{41}$

In a more obvious sense Andrew Lang, who served at some time as president both of the Society for Psychical Research and of the Folklore Society, was an outspoken believer in psychic phenomena, though initially he was also quite critical of psychic research. His name has lost much of its prestige as his (later) theory on "savage high Gods" is particularly unpopular in later twentieth and twenty-first century religious studies (though it is often much misunderstood). How does this all influence his researches into primitive religion, filling many volumes? ${ }^{42}$ A story well-known in Folklore history is the years-long conflict between Andrew Lang and Edward Clodd which strained the Folklore Society from 1895 on, when the medium Eusapia Palladino (1854-1918) was debunked at the Cambridge home of Frederic W. H. Myers, till about 1901. Can modern occult mediumistic phenomena help to understand ancient societies, their religions and the experiences expressed in their religious ideas? Lang defended this approach (Cock Lane and Common-Sense ${ }^{43}$ passim; also in his

38 Edwin S. Hartland, "The Relations of Religion and Magic," in Ritual and Belief: Studies in the History of Religion, ed. Edwin S. Hartland (New York: Charles Scribner's Sons, 1914).

39 James G. Frazer, The Golden Bough: A Study in Comparative Religion, 2 vols. (London: Macmillan, 1890); James G. Frazer, The Golden Bough: A Study in Magic and Religion, 12 vols. + Aftermath, 3rd ed. (London: Macmillan, 1906-1937).

40 Edward Clodd, Tom Tit Tot: An Essay on Savage Philosophy in Folk-tale (London: Duckworth, 1898).

41 Cf. already Edward Burnett Tylor, "Images and Names," in Researches into the Early History of Mankind and the Development of Civilization, new ed. (London: Routledge, 1994), 106-149.

42 Cf. e.g. Andrew Lang, The Making of Religion, 2nd ed. (London: Longmans, Green, and Co., 1900); Lang, Myth, Ritual and Religion, 2nd ed. (London: Longmans, Green \& Co., 1906); Lang, Modern Mythology (London: Longmans, Green, and Co., 1897); Lang, Magic and Religion; Lang, Method in the Study of Totemism, (Glasgow: Maclehose 1911) and others; cf. Roger L. Green, Andrew Lang: A Critical Biography (Leicester: Ward, 1946), 241-259.

43 Andrew Lang, Cock Lane and Common-Sense, new ed. (Cambridge: Cambridge University Press, 1896). 
introduction to Kirk's Secret Commonwealth, ${ }^{44}$ and in many other publications). The rationalist Clodd, the biographer of Darwin and Thomas Huxley, Chairman of the Rationalist Press Association from 1906 to 1913, vehemently denied such a possibility, and declared scholars who used modern occult and spiritualist parallels to understand ancient religions and magic as being obscurantist. His later book The Question: A Brief History and Examination of Modern Spiritualism $(1917)^{45}$ launches a frontal attack on all kinds of occult discourses. This whole discussion of course is not finally concluded even today. Frazer in a letter from 1917 addressed to Edward Clodd called it a scandal that some of the best scientific minds (which he concedes) should be advocates for the Society for Psychical Research, which for him meant: for occultism. Andrew Lang he saw more as a man of letters than of science, and that perhaps the most enduring of his works might prove to be his poems. This is a seriously insulting remark about a scholar who wrote many books on religion, ritual, magic and folk tradition, though Frazer speaks only in a private letter. ${ }^{46}$ We sense the deep irritation the rationalist Frazer experiences by the work of scholars as Lang, or indeed by all scholarship that questioned his feeling of superiority towards religion as such and certainly towards magic.

Lang himself already in Cock Lane and Common-Sense (first edition 1894) had tried to bring folklore studies, psychic studies, anthropology and comparative religion into some productive dialogue. Lang can be seen as a central figure in our debate about the hidden agenda in early Religious Studies. In his essay "Anthropology and Religion" that became part of his later work The Making of Religion (second edition 1900) he wrote:

Pleasantly enough, Anthropology has herself but recently emerged from that limbo of the un-recognised in which Psychical Research is pining. The British Association used to reject anthropological papers as 'vain dreams based on travellers' tales.' No doubt the British Association ${ }^{47}$ would reject a paper on clairvoyance as a vain dream based on old wives' fables, or on hysterical imposture. Undeniably the study of such themes is hampered by fable and fraud, just as anthropology has to be ceaselessly on its guard against 'travellers' tales,' against European misunderstandings of savage ideas, and against

44 Andrew Lang, Kirk's Secret Commonwealth: The Secret Commonwealth of Elves, Fauns \& Fairies; A Study in Folk-lore \& Psychical Research. Text by R. Kirk, M.A., Minister of Aberfoyle, A.D. 1691, commented by A. Lang (London: Nutt, 1893).

45 Edward Clodd, The Question: A Brief History and Examination of Modern Spiritualism (London: Richards, 1917).

46 Robert Ackerman, Selected Letters of Sir J.G. Frazer (Oxford: Oxford University Press, 2005), 317, 351.

47 A British science institution that as it seems is mentioned here pars pro toto for any kind of official, institutionalized science. 
civilised notions and scientific theories unconsciously read into barbaric customs, rites, traditions, and usages. [. . .] For these sound reasons official science long looked askance on Anthropology. Her followers were not regarded as genuine scholars, and, perhaps as a result of this contempt, they were often 'broken men,' intellectual outlaws, people of one wild idea. To the scientific mind, anthropologists or ethnologists were a horde who darkly muttered of serpent worship, phallus worship, Arkite doctrines, and the Ten Lost Tribes that kept turning up in the most unexpected places. Anthropologists were said to gloat over dirty rites of dirty savages, and to seek reason where there was none. The exiled, the outcast, the pariah of Science, is, indeed, apt to find himself in odd company. [. . .] But there was found at last to be reason in the thing, and method in the madness. Evolution was in it. ${ }^{48}$

This passage from Lang allows for some interesting observations about outside perspectives on the new sciences of anthropology and comparative religion. The "anthropologists" we are talking about did not have clear cut academic careers, and they were seen by the academic public as moving in the vicinity of occult and "savage" believe systems. Tribal lore, magic, primitivism and atavism as fields of research made them suspicious. They were very far from being publicly recognized, and their occupation was always moving on the brink on being seen as a pseudo-science dealing in "dirty savages": exactly this is the context that brought Religious Studies into being, at least in Great Britain. Looking back after 150 years, it may have been to the best of the new science it could not stage its own authority, but had to struggle for respectability. In the first edition of Cock Lane and Common-Sense Lang wrote:

When Anthropology first challenged the interpretation of myths given by philologists, we were told that Anthropology relied on mere travellers' tales. It was answered that the coincidence of report, in all ages and countries, and from all manner of independent observers, unaware of each other's existence, was a strong proof of general accuracy, while the statements of learned and scholarly men, like Codrington, Callaway, and many others, confirmed the strange stories of travellers like Herodotus, of missionaries, traders and adventurers. The same test of evidence, universally coincident, applies to many of the alleged phenomena in this book (Preface).

"Test of evidence" is what we might call experience-based science, which (as Lang of course was well aware of) cannot be interpreted without a theoretical reference frame. Müller also had written about the resistance against comparative religions and comparative language studies by those who feared it might result in "the risk of losing the firm grasp which we ought to have on the few [i.e. languages and religions] that are really important". ${ }^{49}$

48 Lang, Making of Religion, 39-40.

49 Müller, Introduction to the Science of Religion, 8-9. 
Analysing the comparative religion writers we have in view, we can easily discern two "types" or mental profiles: strict rationalists as Tylor, Frazer and Clodd, and writers with mystical and perhaps to some degree occult inclinations as Lang, James, Leland, who usually are also interested in psychic studies. Müller and Smith are a kind of middle case, personally connected to a philosophical religion with a Christian background, though Müller denied the idea of special revelation, and was inclined towards mysticism. ${ }^{50}$ Andrew Lang is perhaps the most interesting scholar for our particular question. Some remarks about his inner biography will be illuminating. We happen to know exactly what he read as a student. ${ }^{51}$ In St. Andrews University, where he had been immatriculated in 1861, he was fascinated by Paracelsus and Petrus of Abano, Cornelius Agrippa and the alchemists, and of course by Lord Bulwer-Lytton, the most important Victorian author of occult novels, and a main source of theosophical thinking. On the list of book he got from the library we find writers and titles as Iamblichus and Michael Scotus, Benvenuto Cellini, the Grimm brothers, the Mabinogion, Giambattista della Porta and books on alchemy. Particularly Agrippa seems to have fascinated him. He was disappointed by the grimoires he read, however. Now what does this prove? Does it prove anything? Andrew Lang is a pivotal figure in other areas also. He was by far the most successful author of the group we discuss (his fairy book collections were to be met in every Victorian household), and he was the main antagonist of Frazer. His Magic and Religion is a detailed discussion of The Golden Bough, and in his criticism he anticipates what later became commonplaces of postFrazerian arguments, as for example with Jonathan Z. Smith (1938-2017), who wrote his thesis The Glory, Jest and Riddle: James George Frazer and The Golden Bough ${ }^{52}$ much in the same vein. No other British Victorian mainstream writer on religion illustrates so clearly the deep connection between folklore studies, comparative religion and the occult underground as Andrew Lang.

50 Cf. Marjorie Wheeler-Barclay, The Science of Religion in Britain, 1860-1915 (Charlottesville: University of Virginia Press, 2010), 57.

51 Green, Andrew Lang, 20-21.

52 Jonathan Z. Smith, “The Glory, Jest and Riddle: James George Frazer and The Golden Bough," (PhD diss., University of Yale, 1969). 


\section{Basic Agendas I: The Unity of Religions, Past and Future}

The pathos to find a common ground for religions or a basic unity of religions might be called another common endeavour between occultism and comparative religion. This basic idea has very different faces, of course. It can relate to a primordial wisdom religion in the background of more recent religions, which more or less pass it on, it can apply to a common denominator of religions as they actually are, or it may relate to concepts of a future unity between religions that can be prepared by interreligious dialogue. Both Theosophy and Müllerian science of religion want to develop a new religion in harmony with both science and philosophy though their approaches are completely different, and both believed that such a religion of the future would come when Western and Eastern ideas would go together. Even E. B. Tylor who was much more an agnostic than Müller concludes his work on Primitive Culture with some reluctant ideas about the future of religion, and the part science may play in bringing it to light. Like many Victorians he feared atavism, the backsliding of evolution. In atavism (i.e. anachronistic survival) magic and animism might come back with full force: survival becomes revival. The science of culture in such cases is a reformer's science. ${ }^{53}$

In occultism ideas on the underlying unity of religions also have an aspect of defining an agenda critical of present religions, particularly of Christianity. This attitude can take two forms: the Blavatsky variant where Buddhist and Hindu ideas (in a Westernized interpretation) give shape to the basic reference frame, and the Christian Theosophy variant, where the paradigm includes Neoplatonic, Christian and Hermetic elements. Occultist authors to some degree competing with Helena Blavatsky in their concepts of the unity of all religion (and of science and philosophy) have e.g. been Anna Kingsford (1846-1888), Christian mystic, some-time theosophist, animal rights activist and the second English woman to receive a degree in medicine, and also (with Edward Maitland) author of The Perfect Way; or, the Finding of Christ. ${ }^{54}$ A second example even more clearly trying to bring all religions into one common paradigm is Marie Countess of Caithness, Duchess de Pomár, The Mystery of the Ages Contained in

53 Tylor, Primitive Culture, vol. 2, 453.

54 Anna Kingsford and Edward Maitland, The Perfect Way; or, The Finding of Christ, 7th ed. (London: Field \& Tuer, 1882; Macoy: Publishing \& Masonic Supply Company 1919). 
the Secret Doctrine of all the Ages. ${ }^{55}$ This encompasses a wide range of questions on religion, avoiding any too close contacts with Blavatskyan Theosophy, but shares with her a deep interest in Asiatic traditions. Lady Caithness explicitly refers to Müller and their shared appreciation of such interests, though her own "Wisdom-Religion" is something quite different than what Müller had in mind. Müller disagrees sharply with any mystification of older religions:

\begin{abstract}
Readers who have been led to believe that the Vedas of the ancient Brahmans, the Avesta of the Zoroastrians, the Tripitaka of the Buddhists, the Kings of Confucius, or the Koran of Mohammed are books full of primeval wisdom and religious enthusiasm, or at least of sound and simple moral teaching, will be disappointed on consulting these volumes. Looking at many of the books that have lately been published on the religions of the ancient world, I do not wonder that such a belief should have been raised; but I have long felt that it was high time to dispel such illusions, and to place the study of the ancient religions of the world on a more real and sound, on a more truly historical basis [. . .]. The time has come when the study of the ancient religions of mankind must be approached in a different, in a less enthusiastic, and more discriminating, in fact, in a more scholarlike spirit. ${ }^{56}$
\end{abstract}

We see here the common origin and also the parting of ways between Theosophy and comparative religion. Strangely in his Theosophy, or Psychological Religion with its philosophical ideas about the divine Logos in diverse religions Müller comes much nearer to Caithness and Blavatsky than he seems to have realized. He not just compares Indian Vedanta, Christian Logos theology and Muslim (Sufi) mysticism, he states their basic connectedness, and claims a basic common truth. As Madame Blavatsky he defines a higher religion which he sees as the foundation and future of all true religion. A detailed comparison of their approaches - not possible in this small study - might reveal more many more aspects of such unexpected agreement in some basic paradigms. Emma Hardinge Britten (1823-1899), the main historian of American spiritualism, might be mentioned as a further example of an occult approach facing comparative religion. She was a founding member of the Theosophical Society from its first days on, but after come conflict with Helena Blavatsky she left the Society in late 1877, though some contact remained. She saw Spiritualism as the new religion of mankind, and gave an extensive summary of its pre-history and varieties in the religions of the world in her large book Nineteenth Century Miracles. ${ }^{57}$ A much less

55 Marie Countess of Caithness, Duchess de Pomár, The Mystery of the Ages Contained in the Secret Doctrine of all the Ages (London: Wallace, 1887).

56 Müller, The Upanishads, IX-XI.

57 Emma Hardinge Britten, Nineteenth Century Miracles; or, Spirits and their Work in every Country of the Earth: A Complete Historical Compendium of the Great Movement Known as "Modern Spiritualism" (Manchester: William Britten, 1883). 
known, but even more ambitious work is her The Faiths, Facts, and Frauds of Religious History, ${ }^{58}$ which tries to define an overall theory of the development of religions. Such works might be called an occult "comparative religion".

In Europe comparative religion and theosophical "wisdom-religion" to some degree almost are male and female variants of a common departure from Christian theological paradigms. This is over-simplified, of course, and has to be qualified with other differences between the discourses, but the tension between comparative religion and occultism has important gender aspects. It is certainly not methodology and perhaps also not so much some basic pattern of hermeneutics that religious studies have in common with these occult and philosophical systems (and of course they are divided by their fascination with "phenomena" and their esotericism). The common ground they nevertheless share can be seen primarily in the aspects of religion they choose as their objects of reflection, in their obsession with tradition, magic, and other elements allegedly archaic in religion, and secondly in their willingness to see all aspects of religion as part of one living organism that can be explained by common laws, i.e. to look for one true religion not in any "pure" or reformed variety of one specific religion, but in an extract from a multitude of religions. None of the writers we have discussed has ever shown much interest in the diversities of present-day religions: it is the primordial, be it archaic magic, be it "wisdom of the ages" that they are looking for. These are different agendas, but they are deeply related, and can be interpreted as different facets of the Victorian imagination of culture in so far as it pertains to religion. Can we say comparative religion competed with theosophy and similar systems for the hegemony of interpreting religion and defining its basic unity?

\section{Basic Agendas II: The Concept of Comparison in Comparative Religion}

Scientific analysis in late nineteenth century cultural and historical science essentially means comparison. Friedrich Max Müller had already written rather programmatically in 1870:

All higher knowledge is acquired by comparison, and rests on comparison. If it is said that the character of scientific research in our age is pre-eminently comparative, this really means

58 Emma Hardinge Britten, The Faiths, Facts, and Frauds of Religious History (Melbourne: George Robertson, 1879). 
that our researches are now based on the widest evidence that can be obtained, on the broadest inductions that can be grasped by the human mind. ${ }^{59}$

Müller gives the indeed convincing examples that both biology and linguistics achieved its greatest triumphs in the nineteenth century by strict and methodic comparison. To understand religion meant for Müller, Tylor, Smith and without any exception all scholars we have been discussing: to define patterns of comparison. They concentrated on "Aryan" (Indo-Europaean) and Semitic Religions, with occasional sidelights on other religions as they became known. To some degree they looked for wisdom from the East: but not from the Holy Land, as former generations had done, but from sources farther east, "fetishizing the Vedas". ${ }^{60}$

In a similar vein the most important church historian of the early twentieth century, Adolf von Harnack, could write in 1905:

Im 19. Jahrhundert ist die vergleichende Methode geradezu zur Herrscherin in der Wissenschaft geworden. Vergleichende Sprach-, Religions-, Rechts- und Verfassungswissenschaft usw. sind an die Spitze getreten, und keine einzige Disziplin vermag sich dieser Methode zu entziehen. ${ }^{61}$

In more recent historical and cultural sciences of course things have changed completely, and comparison has come under the general suspicion of looking with European and American glasses or perspectives at non-Western people. But it was different in the age we are speaking about. Both comparative religion and occult and theosophical discourses very much participated in this general pattern of the comparative method. The Golden Bough in its first 1890 edition was subtitled A Study in Comparative Religion (later retitled in the second edition: A Study in Magic and Religion). Even more explicit is a passage using a military metaphor contrasting religion and theology with the new science: "Yet sooner or later it is inevitable that the battery of the comparative method should breach these venerable walls, mantled over with the ivy and mosses and wild flowers of a thousand tender and sacred associations. At present we are only dragging the guns into position; they have hardly yet begun to speak". ${ }^{62}$ This passage taking up the nineteenth century language of a "warfare" between science and religion (mostly directed against the Roman Catholic Church) Frazer did not repeat later,

59 Müller, Introduction to the Science of Religion, 9-10.

60 Marchand, characterizing this scholarship in: Suzanne L. Marchand, German Orientalism in the Age of Empire: Religion, Race, and Scholarship (Washington, D.C.: German Historical Institute; Cambridge: Cambridge University Press, 2009), 131.

61 Adolf von Harnack, "Gedanken über Wissenschaft und Leben (1905)," in Wissenschaftspolitische Reden und Aufsätze, ed. Bernhard Fabian (Hildesheim: Olms-Weidmann, 2001), 225; Fabian's edition strangely giving 1907 as date for the statement, which already in 1905 had been printed.

62 Frazer, Golden Bough, vol. 1, 2nd ed., XXI-XXII. 
expressing himself with much more restraint. ${ }^{63} \mathrm{~A}$ few years later Frazer's first biographer, taking down ideas from his almost daily contact with the scholar for many years, wrote: "The most important intellectual achievements of the nineteenth century, it might be maintained, arose not so much from the discoveries of new facts, though these were tremendous, as from the use of a new method of approaching and interpreting these facts. The new weapon was the Comparative Method". ${ }^{64}$ How do the concepts of comparison by these scholars relate to the concept of synthesis as defined by the Theosophical Society? The Secret Doctrine famously was subtitled: The Synthesis of Science, Religion, and Philosophy. ${ }^{65}$ But this is just a first suspicion if we may say so that these writers did not move in completely different agendas as accepted history of the humanities usually has taken for granted, and further discussion is needed.

\section{The Science of Religion in a Social World of Competing Learned Societies}

The new approach of comparative religion has a well-defined social aspect as well, which brings us to look at learned societies and patterns of competition. Such societies in Victorian Britain are a primary forum for discussion on academic or learned subjects. Most of them were not strictly academic in the sense of University affiliation, and membership was open to all interested men (rarely women) of scholarly inclinations. They were the academic and learned equivalent of the gentlemen's club as the (still very intellectual) Athenaeum Club founded in $1824 .{ }^{66}$ The Royal Society, archetype of all such societies, certainly had much more public reputation, but as its membership was strictly qualified and restricted, it is only partially comparable to other learned societies. These also often had specific membership requirements, and quite high fees, which restricted them to upper middle-class and upper-class men. Membership numbers of one or two hundred are common (rarely more: even the Athenaeum Club originally was restricted to 400 members, later to 1000), and as we will

63 Cf. Timothy Larsen, The Slain God: Anthropologists and the Christian Faith (Oxford: Oxford University Press, 2014).

64 Angus R. Downie, James George Frazer: The Portrait of a Scholar (London: Watts, 1940), 9-10. 65 Helena P. Blavatsky, The Secret Doctrine: The Synthesis of Science, Religion, and Philosophy, 2 vols. (London: The Theosophical Publishing Company, 1888).

66 Cf. Seth A. Thévoz, Club Government: How the Early Victorian World was Ruled from London Clubs (London: I.B. Tauris, 2018). 
see, often the same people took part in different societies. Often membership included the receipt of the publications of the society, though there were also "publishing societies" specializing in making sources available as the Roxburghe Club, the Bannatyne Club, the Royal Historical Society and others. Some had a more oriental emphasis as the Royal Asiatic Society Oriental Translation Fund, established in 1828, a subscription printing club organized by the Royal Asiatic Society of Great Britain and Ireland, which itself was founded in 1823. Another medium of communication was the society conference: a form a scientific gathering differing markedly from the meetings of the older academies, and much more open to a wider public.

And they competed. Indeed who competes with whom in public standing is one of the most vital questions in the history of science as well as of religion, particularly in modernity, where such conflicts are often not too obvious: hidden agendas of competition in the science community and in wider society. This will be a basic consideration in this study. As an emerging science, with whom or with what did Religious Studies or comparative religion compete? Which prerogative of interpretation was at stake? Learned societies often came into being by competing ideas about certain subjects. The Anthropological Society of London e.g. was founded in 1863 by Sir Richard Francis Burton (1821-1890) and Dr. James Hunt (1833-1869), breaking away from the older Ethnological Society of London, founded in 1843. It clearly defined itself in opposition to the older society, dealing with physical as well as cultural aspects of mankind. A few years later, in 1871, with a much larger clientele and larger financial possibilities the Royal Anthropological Institute of Great Britain and Ireland (RAI) was founded, open also to non-British members, and again with a much wider schedule of interests than the earlier anthropological societies could express. Its prestigious Huxley Memorial Medal and Lecture, established in 1900 in memory of Thomas Huxley, was given in 1907 to E. B. Tylor, in 1916 to Sir J. G. Frazer, and in 1923 to E. S. Hartland, the only recipients during these years that might be called scholars of religion.

The scientific community perhaps best comparable in its unfolding research and growing deeply inter-connected group of specialized scholars was the field of folklore studies. It will become immediately clear why we mention this here. Its agenda was that of a new science as well: "Folk-lore is a science by itself, with distinct work of its own to accomplish". 67 The Folk-Lore Society (later Folklore Society) was founded in 1878 in London to study traditional vernacular culture,

67 Edwin S. Hartland et al., "Folk-Lore Terminology," The Folk-Lore Journal 2, no. 11 (Nov. 1884), 348. 
folktales, customs etc., with many prominent members, almost all of them somehow also connected to comparative religion. Those scientifically active in the organization have been called the "great team" in Richard Dorson's noted and indispensable history of British folklore studies. These men were Andrew Lang (first non-titled president in 1888-1889), Edwin Sidney Hartland (president 1899-1901), Alfred Trübner Nutt (1856-1910), owner of a publishing house specializing in academic books on folklore and mythology and founder of the Society Journal, and also William Alexander Clouston (1843-1896), William Thoms (1803-1885), the founder and some-time editor of the journal Notes and Queries, who had coined the term "folk-lore" in 1846, Edward Clodd (1840-1930) and Sir George Lawrence Gomme (1853-1916), Sir John Lubbock (1834-1913), also a man quite critical of religion, General-Lieutenant Augustus Fox Pitt Rivers (1827-1900), founder of British archaeology and the driving force behind the Pitt Rivers Museum in Oxford, Alfred Cort Haddon (1855-1940), and also - of lesser fame, but certainly as interesting - the Australian Jew Joseph Jacobs (1854-1916), who became also president of the Jewish Historical Society, and some others. Tylor, Gomme and Lang were also members of the first council of the Folk-Lore Society. Frazer himself was for many years a kind of inactive vice-president of the Folk-Lore Society, and the fields of British folklore studies and British comparative religion overlapped to such a degree that they became partially indistinguishable, particularly in their obsession with "survivals". This ended with the demise of Frazerian and Tylorian approaches as leading anthropological paradigms in the Edwardian era. A slight trace of provocation was not something foreign to these scholars: Gomme wrote a book Folklore as an Historical Science, ${ }^{68}$ Hartland a book The Science of Fairy Tales, ${ }^{69}$ both rather aggressively availing themselves of the word "science" in defence of the new science and its most famous statement: "Folklore is the science of tradition". ${ }^{70}$ Indeed much of the literature on the science of tradition and its early history is of vital importance for the science of religion also; as we have stated they were initially twin sisters, and even The Golden Bough is as much a book on folklore as on magic and religion. Both sciences had a hold on the Victorian intellectual elite: but also both were far from being established in

68 George L. Gomme, Folklore as an Historical Science (London: Methuen, 1908); The leading scholars in the field for him are J. G. Frazer, Sir William Ridgeway, William Warde Fowler, Jane Ellen Harrison and Andrew Lang: Folklore as an Historical Science, 1.

69 Edwin S. Hartland, The Science of Fairy Tales: An Inquiry into Fairy Mythology (London: Scott, 1891).

70 Edwin S. Hartland, Folklore: What Is It and What Is the Good of It? (London: David Nutt, 1899), 7; cf. Richard M. Dorson, The British Folklorists: A History (London: Routledge \& Kegan, 1968), 243. 
the academia. ${ }^{71}$ We have already mentioned the deep divide in folklore studies about the acceptability of material from psychic research for the interpretation of folk tradition.

Many of the discussions about religion took place in these already existing Societies, and we can easily see how a science community primarily organized in the shape of learned Societies differed from a science community living mainly in a University world: a first remarkable point being almost all of the scholars just mentioned earned their livelihood outside of the University field, Tylor and Müller being exceptions, and even they had to wait a long time for appropriate University positions. British comparative religion only to a very limited degree is a product of the University (and we must not forget even Charles Darwin never held a University position, but was a private and independent scholar). Tylor only in 1896 was appointed the first Professor of Anthropology at Oxford University, when he was 64 years old. He had served as a lecturer, and was Keeper of the University Museum at Oxford from 1883. From 1884 to 1896 he held the modest title of Reader in Anthropology, though a world-famous scholar since his Primitive Culture from 1871. Müller after a quite poor youth for some years was a language teacher and editor before he received a chair at Oxford University. Frazer was a successful writer, but completely unable to teach, and he never had a financially secure position. These men only slowly became part of the regular University system. Today we may see these scholars as classic authorities of their sciences: in their own days this is far from being the case. Many of the scholars we have to consider worked as lawyers or literary editors, more rarely as businessmen. Herbert Spencer, the leading "public intellectual" of the Victorian age (particularly in the 1870s, when Frazer was an undergraduate), today best known for coining the term "survival of the fittest" in 1864, started his life as a civil engineer, later being able to support himself solely from the profit of book sales and the income from his contributions to Victorian periodicals, never holding a University chair. He as might be expected also wrote much on religion from an evolutionary point of view. Folklore studies, comparative religion and other new approaches have been "gentlemen sciences" for a long time, with only limited presence at the Universities (apart from the Gifford lectures, the Hibbert lectures and similar projects which are discussed in the longer version of this study).

71 Cf. also on "gypsy research" and the Gypsy Lore Society, founded in 1888, with the witchcraft scholar Charles Godfrey Leland as its first president, Frenschkowski, "Charles Godfrey Leland (1824-1903) und die Ursprünge der Wicca-Religion”; Deborah E. Nord, Gypsies and the British Imagination, 1807-1930 (New York: Columbia University Press, 2006). It had virtually the same clientele as folklore studies and comparative religion. 
Though often personally in a relation of friendly mutual interest, the scholars we have to consider also to some degree competed for public recognition with their different ideas on their new sciences. Rivalry effects a change in all participants: a scholar will not be the same with such a hidden agenda at his back, even if an open conflict never occurs. Comparative religion as is one of the basic assumptions of the present study can only be understood by taking into account such competition. What were its rivals and who already by this constellation influenced its agenda? This in some sense is both supplementary and in some opposition to the question put by Louis Henry Jordan (1855-1923), the first historiographer of the new science, in a study called Comparative Religion: Its Adjuncts and Allies. ${ }^{72}$ The new science did not only have allies (as folklore studies): it had competing rivals, and as we will see the Theosophical Society has been one of its major rivals. The place of occult discourses and ideas in Victorian society has been a subject of many studies in recent years, ${ }^{73}$ of course, but they have so far not been examined in relation to the early study of religion in an anthropological context. ${ }^{74}$

\section{A Well-known Example of a Cain-Abel Conflict: Theosophical Society vs. S.P.R.}

An evident example of this perspective looking for affinity and competition is the relation between the Theosophical Society of Madame Blavatsky (founded 1875) and her adherents and the Society for Psychical Research (S.P.R., founded 1882). We take a very short look at this conflict as it is the clearest and perhaps most well-known example of the kind of competitive constellation we are characterizing, covering or hiding a deeper affinity. Both Societies dealt with psychic "forces", with hidden abilities of man, with phenomena outside accepted knowledge. But otherwise they moved in completely different cultural milieus,

72 Louis H. Jordan, Comparative Religion: Its Adjuncts and Allies (London: Oxford University Press, 1915).

73 Cf. e.g. Alex Owen, The Place of Enchantment: British Occultism and the Culture of the Modern (Chicago: Chicago University Press, 2004).

74 Owen, Place of Enchantment.; J. Jeffrey Franklin, Spirit Matters: Occult Beliefs, Alternative Religions, and the Crisis of Faith in Victorian Britain (Ithaca: Cornell University Press, 2018) and even the excellent study by Wouter J. Hanegraaff, Esotericism and the Academy: Rejected Knowledge in Western Culture (Cambridge: Cambridge University Press, 2012) do only lightly touch on the question. 
with different agendas and target audiences, and their final "parting of ways" is a classic disastrous Cain and Abel-conflict. The S.P.R. as is well-known avoided even the word "occult, occultism" in its early publications (though its library contained all the classics in the field). The chain of events was inaugurated by the so-called Hodgson Report of 1885. The relationship between the two Societies initially had not been unfriendly, and indeed the personal contacts between some of the leaders were quite open-minded. The perhaps most renowned member of the S.P. R., to give an example, had been Sir William Crookes (1832-1919), theoretical physicist and inventor of a prototype of the TV tube and fluorescent lightning, and some time President of the Royal Society (he was elected a member in 1863 for his discovery of a new chemical element, Thallium) as well as President of the S.P.R. (in 1897). In 1867 he also became interested in Spiritualism after the death of a brother. As is happens, William Crookes, his wife, and also Charles W. Leadbeater (later a leading theosophist) joined the Theosophical Society on the same day, November 20,1883. ${ }^{75}$ At this time both Societies were not in any kind of animosity. Crookes is mentioned a number of times in the Mahatma letters, and very often in the writings of Madame Blavatsky. ${ }^{76}$ Crookes in 1884 even invited Olcott (co-founder of the Theosophical Society) and an Indian friend into his laboratory to visit his experiments. ${ }^{77}$

We will take a quick glance at some other members of the S.P.R. and their relation to Theosophy, before turning to the story of the parting of ways between both Societies. We gain the impression many people in the S.P.R. field, the anthropology and folklore research field and this means also the Religious Study fields were connected, often by private relationships. Well-known members of the S.P.R. have been its first President, Henry Sidgwick (1838-1900), Knightbridge Professor of Moral Philosophy at Cambridge University. His wife, Eleanor Mildred Sidgwick, also a noted author on S.P.R. subjects (even more than her husband; also Principal of Newnham College 1892-1910 and first female president of the S.P.R. 1908-1909), was a sister to Arthur Balfour (1848-1930), Prime Minister of the United Kingdom from 1902 to 1905 and Foreign Secretary from 1916 to 1919 (famous for the Balfour Declaration in November 1917 on behalf of the cabinet) - and himself President of the S.P.R. from 1892-1894 (he also delivered the Gifford Lectures at the University of Glasgow in 1914). These connections

75 Philip S. Harris et al., eds., Theosophical Encylopedia (Quezon City, Philippines: Theosophical Publishing House, 2006), 179.

76 Cf. e.g. A. Trevor Barker, transc., The Letters of H. P. Blavatsky to A. P. Sinnett and other Miscellaneous Letters (Pasadena: Theosophical University Press, 1973), 224-229.

77 Henry St. Olcott, Old Diary Leaves 3 (New York: G.P. Putnam's Sons, 1895-1935), 99; cf. 102-104. 
well illustrate the academic and upper-class character of the S.P.R., though as a learned society it never gained the academic standing it tried to achieve. In contrast to Crookes, Myers, Podmore and others, Sidgwick is not known to have been interested in Theosophy. Sir Oliver Lodge (1851-1940), principal of the University of Birmingham 1900-1920 and as a physicist inventor of the radio wave detector, has been President of the S.P.R (1901-1903, and again in 1932), and was a devoted spiritualist in his later years. Andrew Lang, Frazer's most noted opponent, held the position of President of the S.P.R. in 1911. Another of the best-known researchers of the S.P.R., Frederick W. H. Myers (1843-1900), co-author with Frank Podmore and Edmund Gurney of Phantasms of the Living, ${ }^{78}$ a bulky two-volume work on hallucinations, telepathy and similar phenomena, was not just a psychic researcher but also for some time a theosophist. He joined the Theosophical Society on June 3, $1883 .^{79}$ After the Hodgson report he changed his mind, and became increasingly disillusioned and bitter about Madame Blavatsky and Theosophy. The Hodgson Report may be seen as the crossroads where Theosophy and occultism became sub-cultural movements in Victorian culture, comparable to the manner the homosexual sub-culture became almost invisible in London for a few years after the court case against Oscar Wilde in 1895. Charles Robert Richet (1850-1935), though of French nationality, we may mention as a further example of the high social milieu of psychical research. In 1905 he has been President of the S.P.R., and he also was an avid spiritualist and theosophist, even writing articles for the German theosophical magazine Sphinx. ${ }^{80}$ As a physiologist and psychologist he received the Nobel Prize for medicine in 1913.

The preliminary meetings and also some later meetings of the steering committee of the S.P.R. met at the personal home of Charles Carleton Massey (1838-1905), a lawyer and private scholar who also had translated writings of Paracelsus and Franz Hartmann into English. But Massey was also the chief organizer of the English branch of the Theosophical Society, the founding meeting of which on 27. Juni 1878 took place in 38 Great Russell Street, London, which as it happens also was the head quarter of the British National Spiritualist

78 Frank Podmore and Edmund Gurney, Phantasms of the Living (London: Trübner \& Co., 1886).

79 Boris de Zirkoff, “Compiler's Note,” in Helena P. Blavatsky, Collected Writings, comp. Boris de Zirkoff, vol. 5 (Wheaton: Theosophical Publishing House, 1966-1991), 264; cf. also Blavatsky, Collected Writings, vol. 7, 319, 332.

80 Norbert Klatt, Der Nachlaß von Wilhelm Hübbe-Schleiden in der Niedersächsischen Staatsund Universitätsbibliothek Göttingen: Verzeichnis der Materialien und Korrespondenten mit biobibliographischen Angaben (Göttingen: Klatt, 1996), 234. 
Alliance, the first president of which Massey was. ${ }^{81}$ Such connections are of the utmost importance to understand the intellectual milieu in which we are moving.

If we take a look from the other side, in 1884 the London Lodge of Theosophy had members as Archibald Keightley (1859-1930), the newspaper editor A. P. Sinnett (1840-1921), Dr. Anna Kingsford (1846-1888, most famous Christian esotericist of her days), William Kingsland (1855-1936, first president of the Blavatsky Lodge), William Crookes, Frank Podmore, F. W. H. Myers, Edmund Gurney (the last four also leading members of the S.P.R.) and Charles Massey. ${ }^{82}$ They represented quite a substantial part of the London scene of scholars interested in alternative religion and psychic studies. Massey, a barrister, as we mentioned was a founding member both of the Theosophical Society and the S.P.R. (and of its Council 1882-1886), and as a near acquaintance of Madame Blavatsky also the first president of the British Theosophical Society, the first Branch outside the USA. His father had been Minister of Finances in India. William James (1842-1910), the most well-known psychologist of the USA, president of the S.P.R. in 1896, and co-founder of its American daughter society, was also for some time a member of the Theosophical Society, ${ }^{83}$ quoting texts like Blavatsky's The Voice of the Silence. ${ }^{84}$ We mention these names to exemplify the social and intellectual milieu we are dealing with. The member fluctuation between the Theosophical Society and the S.P.R. was already noted by contemporaries as Alfred Sinnett ${ }^{85}$ and even by Madame Blavatsky herself. ${ }^{86}$ The aspect of personal relations in such conflicts must never be overlooked. To mention just one example from many possible ones: Lady Emily Lutyens (1874-1964), wife of a famous architect. She had been active in social work for prostitutes, and fought for the

81 De Zirkoff, “Compiler’s Note,” in Blavatsky, Collected Writings, vol. 1, 498.

82 Cf. for this short list Gregory J. Tillett, “Charles Webster Leadbeater 1854-1934: A Biographical Study” (PhD diss. University of Sidney 1986), 1065 n. 2.

83 Philip S. Harris et al., eds., Theosophical Encyclopedia (Quezon City, Philippines: Theosophical Publishing House, 2006), 327.

84 Helena P. Blavatsky, "The Voice of the Silence," in The Varieties of Religious Experience: A study in Human Nature, ed. Wiliam James (Cambridge: Cambridge University Press, 1902), 379-380. His interest in psychic research has always been known (a collection of relevant texts is: Gardner Murphy and Robert O. Ballou, William James on Psychical Research (London: Chatto \& Windus, 1961), but only in 2017 a study by Krister D. Knapp, William James: Psychical Research and the Challenge of Modernity (Chapel Hill: University of North Carolina Press, 2017) making available new sources could demonstrate how central this subject in fact has been for James' research agenda.

85 Alfred P. Sinnett, The Early Days of Theosophy in Europe (London: Theosophical Publishing House, 1922), 65.

86 Helena P. Blavatsky, The People of the Blue Mountains (Wheaton: Theosophical Press, 1930), 150-151. 
female right to vote. Annie Besant converted her to Theosophy, and later she became a kind of second mother for Krishnamurti when he spent time in Britain. But she also was a born Lady Lytton and a grandchild of Bulwer-Lytton, the most important Victorian author on the occult, and she was a sister-in-law of Gerald Balfour, who as his brother Arthur had become president of the Society for Psychical Research, the first one in 1906/7, Arthur already in 1893. Now the sister of the Balfour Brothers, Nora, was married to Henry Sidgwick, the founding president of the S.P.R. The sister of Henry, Mary, was the wife of Edward White Benson and mother of the famous Robert Hugh Benson and the Benson brothers, and so on.

The friendly terms between both Societies changed completely in 1885, as is well known. A young lawyer, Richard Hodgson (1855-1909), ${ }^{87}$ not yet 30 years old, was sent to India to collect evidence related to some articles accusing Helena Blavatsky of fraud. (The expenses of his voyage were paid for privately by Henry Sidgwick, as the members of the S.P.R. should not be burdened in case the investigation came to nothing). The later verdict of the Committee of the Council of the Society for Psychical Research was clear: Madame Blavatsky "has achieved a title to permanent remembrance as one of the most accomplished, ingenious, and interesting impostors in history". ${ }^{88}$ It is difficult today to get a clear scenario about the charges, particular as Blavatsky did not get any serious chance of self-defense. Hodgson for his career clearly needed a spectacular exposure, he never showed Madame Blavatsky the letters allegedly written by her, and he clearly behaved in a way regarded as highly offensive by the Indian native residents at Adyar. ${ }^{89}$ The relation between the S.P.R. and the Theosophical Society itself is rather complex and can be seen as a kind of competitive Cain-Abel conflict. It perhaps should be interpreted as a competitive struggle for the prerogative of interpretation of psychic phenomena, of the unknown and not easily recognizable aspects of the soul.

87 Cf. for a biography Alexander T. Baird, Richard Hodgson: The Story of a Psychical Researcher and his Times (London: Psychical Press, 1949).

88 Richard Hodgson, "An Account of Personal Investigations in India and Discussion of the Authorship of the "Koot Hoomi” Letters": Together with: Report of The Committee Appointed to Investigate Phenomena Connected with the Theosophical Society, Proceedings of the Society for Psychical Research 3 (1885), 201-400 (different authors and documents; Hodgson's own report is pp. 207-317), 207.

89 Cf. for full details from a forensic researcher: Vernon Harrison, H. P. Blavatsky and the SPR: An Examination of the Hodgson Report of 1885 (Pasadena: Theosophical University Press, 1997). 


\section{Madame Blavatsky and Max Müller: What the Competition Means}

A similar conflict can be seen between comparative religion and the Theosophical Society and some affiliated groups. The subject of the argument of course is a different one, defining the underlying unity of religion, and by this perhaps even defining the future of religion. Who is the accepted interpreter of religion, when Christian theology is losing its monopoly status of interpreting religion? In the multi-voiced choir of emerging sciences and philosophies, who will be held responsible to understand and publicly explain "religion"? The battle for authority and public standing in the act of interpreting religion had just started in the late nineteenth century (it is very much going on even in the twenty-first century, of course).

A good example of this conflict is the argument between Madame Blavatsky and Friedrich Max Müller. This indeed is not so much an argument but a case of jealousy on both sides. Blavatsky often does not so much argue with Friedrich Max Müller, but writes with rather grudging disdain about the public recognition Müller had received. There is no scholar of religion she quotes more often than Müller. But we will have to look at Müller, as we are here concerned more with his side of the competition, and he is not free from jealousy about the public attention Theosophy receives, either. "The science of religion is only just beginning”, Müller wrote in 1860, ${ }^{90}$ and Madame Blavatsky quotes this passage in the introductory remarks of her "Theology"-volume in Isis Unveiled. ${ }^{11}$ Indeed she quotes and mentions Müller more than eighty times in Isis Unveiled alone, and quite often even in her many smaller articles. Both share the conviction the religions of the world are a kind of very rich foreign continent just in the earliest days of its colonization. Both see themselves as explorers of new areas of knowledge: and as such they get into some rivalry. Blavatsky and Müller never met in person, though this seems to have been planned a number of times. ${ }^{92}$

Müller's own attitude is most clearly visible in his Gifford lectures from 1892, published 1893 as Theosophy or Psychological Religion. A bit smugly he chooses

90 Friedrich Max Müller, "Semitic Monotheism," in Chips from a German Workshop, 1st vol. new ed. (New York: Charles Scribner’s Sons, 1900-1907), 373.

91 Helena P. Blavatsky, Isis Unveiled: A Master-key to the Mysteries of Ancient and Modern Science and Theology, 2 vols. (New York: J. W. Bouton/London: Bernard Quaritch, 1877).

92 Cf. Isaac Lubelsky, "Friedrich Max Müller vs. Madame Blavatsky: A Chronicle of a (very) Strange Relationship," in Theosophical Appropriations: Esotericism, Kabbalah, and the Transformation of Traditions, ed. Julie Chajes and Boaz Huss (Beer Sheva: Ben-Gurion University of the Negev Press, 2016), 85-86. 
the word Theosophy, thereby clearly trying to repossess the time-honoured sobriquet in an academic context. In the preface he writes:

I ought, perhaps, to explain why, to the title of Psychological Religion, originally chosen for this my final course of Gifford Lectures, I have added that of Theosophy. It seemed to me that this venerable name, so well-known among early Christian thinkers, as expressing the highest conception of God within the reach of the human mind, has of late been so greatly misappropriated that it was high time to restore it to its proper function. It should be known once for all that one may call oneself a theosophist, without being suspected of believing in spirit-rappings, table-turnings, or any other occult sciences and black arts. ${ }^{93}$

Müller defends himself against the suspicion of any affinity to occultism, and sees his lectures as a counter-project against an explicit rival: which is the Theosophical Society. Reading this his major book on religious philosophy with a 130 years distance we can clearly see, however, how much his schedule of preferred subjects is identical with that of the Theosophical Society though his ideas and his philosophical agenda were different. He is fascinated by ancient gnosticism, by Alexandrian logos theology, by Vedanta and Sufism, and by Christian mysticism far from public Victorian religion or church life. Though he never deals in new revelations, his mystic Christianity with its deep sympathy for Asian religions and its pathos of pure and unspoilt Aryan religion is not really so far from esotericism, something he of course would probably not have complied with.

Müller was both deeply interested in and irritated by Madame Blavatsky and commented quite often on her and her Indian connections. This has been documented a number of times and need not be repeated here. ${ }^{94}$ of course he was no sympathizer. He harshly denounced Madame Blavatsky e.g. in an 1893 article in the influential magazine The Nineteenth Century. He particularly denied any kind of esotericism in both Hindu and Buddhist earlier teachings, ${ }^{95}$ and he severely criticized theosophists not only for the many misunderstandings of Hindu and Buddhist tradition and westernizing ideas about the secret doctrine, but most of all for the very idea about arcane teaching at the core of these religions. In the (only seemingly) simple question about the importance and existence of arcane teaching as a part of early Eastern tradition, however, Blavatsky perhaps was more right than Müller, though much of what she told

93 Friedrich Max Müller, Theosophy or Psychological Religion (London: Longmans, Green and Co., 1893), XVI; cf. Georgina A. Müller, ed., The Life and Letters of the Right Honourable Friedrich Max Müller, vol. 2 (New York: Longmans, 1902), 304.

94 De Zirkoff in: Blavatsky, Collected Writings, vol 5, 378-379; Lubelsky, "Friedrich Max Müller". 95 Cf. Blavatsky, Collected Writings, vol. 13, 146; Blavatsky, Collected Writings, vol. 14, 3-6, 446. 
about it was her own invention. Müller clearly overdid his point when denying anything esoteric in Buddhism, even when considering early Buddhism, but much more when facing Mahāyāna and Vajrayāna. ${ }^{96}$ Müller wanted to see Indian early religion much as a global philosophy, completely underrating other aspects. He at least praised the Theosophical Society for its impact on the endeavours to translate Indian books into English. ${ }^{97}$ In this regard he competed with the Theosophical Society: his own counter-theosophy was as little a piece of Christian tradition as was Blavatskyan Theosophy, and both tried to bring East and West together. By this they both take up a basic end-nineteenth-century challenge ("Oh, East is East, and West is West, and never the twain shall meet” Rudyard Kipling, The Ballad of East and West, 1889). A quite personal document illustrating Müller's direct personal contact with theosophists is a letter Müller wrote to Olcott in 1893 after Madame Blavatsky had died, discussing the question of esotericism in Buddhism, and illuminating the quite personal and friendly tone of the latter should also be noted, Müller writing as an older German-British scholar to the nine years younger American Olcott. ${ }^{98}$

Both comparative religion and Theosophy were certainly rivalling to some degree Christian theology (mostly missionary theology), but even more importantly they were rivals with each other in defining a new approach to nonChristian traditions. This did not necessitate unrespectful relations, however. Blavatsky criticises at length a Sanskrit poem by F. Max Müller, though she says theosophists have for Müller "always had a profound respect". 99 In an earlier article she writes:

\footnotetext{
And it is also due to the unremitting labours of such Orientalists as Sir W. Jones, Max Muller, Burnouf, Colebrooke, Haug, de Saint-Hilaire, and so many others, that the [Theosophical] Society, as a body, feels equal respect and veneration for Vedic, Buddhist, Zoroastrian, and other old religions of the world; and, a like brotherly feeling towards its Hindu, Sinhalese, Parsi, Jain, Hebrew, and Christian members as individual students of 'self,' of nature, and of the divine in nature. ${ }^{100}$
}

Madame Blavatsky even cites Müller approvingly whenever possible, as on a basic unity between Islam and Christianity. ${ }^{101}$ She explicitly takes it for granted that simply every of her possible readers knows Müller's theories on religion. ${ }^{102}$

\footnotetext{
96 Cf. Müller, Life and Letters, vol. 2, 309.

97 Blavatsky, Collected Writings, vol. 12, 299.

98 Müller, Life and Letters, vol. 2, 312-314.

99 Blavatsky, Collected Writings, vol. 13, 104-110. Quotation: 104.

100 Blavatsky, Collected Writings, vol. 2, 104.

101 Blavatsky, Secret Doctrine, vol. 1, 41.

102 Blavatsky, Secret Doctrine, vol. 1, 31.
} 
But there are other voices as well; in one case she even wrote to her sister: [I] "went deep into thought about a certain Sanskrit book which I thought would help me to make good fun of Max Muller in my magazine". ${ }^{103}$ She insisted on the limitations of Western scholarly knowledge about the mysteries of Eastern faiths:

The late Swami Dayanand Sarasvati, the greatest Sanskritist of his day in India, assured some members of the Theosophical Society of the same fact with regard to ancient Brahmanical works. When told that Professor Max Müller had declared to the audiences of his 'Lectures' that the theory. . .. 'that there was a prime magical preternatural revelation granted to the fathers of the human race, finds but few supporters at present,' - the holy and learned man laughed. His answer was suggestive. 'If Mr. Moksh Mooller, as he pronounced the name, 'were a Brahmin, and came with me, I might take him to a gupta cave (a secret crypt) near Okhee Math, in the Himalayas, where he would soon find out that what crossed the Kalapani (the black waters of the ocean) from India to Europe were only the bits of rejected copies of some passages from our sacred books. There was a 'primeval revelation', and it still exists; nor will it ever be lost to the world, but will reappear; though the Mlechchhas will of course have to wait. ${ }^{104}$

Competition between Theosophy and Christian theology is obvious: but this more hidden competition on both sides between Müller and Blavatsky is a specimen of the more general agenda we suggest for the early days both of comparative religion and folklore studies. Charlotte S. Burne, a female scholar of folklore, in an 1887-1888 article explicitly discussed how the Folk-Lore Society should proceed to gain publicity and members in the same manner the S.P.R. and more generally spiritualism successfully do: "we ought to gain the attention of the newspapers. What the Psychical Society can do, surely the Folk-Lore Society can”, she writes. She clearly saw the Folk-Lore Society in direct competition to the milieu of psychical research. ${ }^{105}$

Competition existed of course also in the occult and alternative spirituality field as such. Theosophy and spiritualism have been rivals from the beginning. ${ }^{106}$ But also the Hermetic Order of the Golden Dawn competed with Theosophy, and Madame Blavatsky reacted to its appeal by the foundation of the Esoteric Section in London 1888, which she personally supervised. Golden Dawn's Flying roll $X X$ (one of a set of occult teachings given only internally to

103 W. Q. Judge, “Letters of H. P. Blavatsky,” Part 4, The Path (Dec. 1894-Dec. 1895).

104 Blavatsky, Secret Doctrine, vol. 1, XXX; Mlechchhas, today mostly written mleccha, being a Hinduist derogatory term for non-Indians as "barbarians".

105 Cf. Robert Ackerman, J. G. Frazer: His Life and Work (Cambridge: Cambridge University Press, 1987), 101.

106 Cf. Marco Frenschkowski, "Theosophy, Magic and the Literary Imagination: Remarks on H. P. Blavatsky," in Fictional Practice: Magic, Narration and the Power of Imagination edited by Bernd-Christian Otto (Leiden: Brill, 2021). 
members, for a certain fee) defines the difference: "This is why, in our system of Occultism we are contrary or converse to that taught by the Theosophical Society. The Theosophists apparently advise the student to commence with the study of the Universe, and while I quite agree that he may arrive at his end by that means, there is the danger of that thought-selfishness, and this is then reason why we study the Microcosm before the Macrocosm". ${ }^{107}$ This means Theosophy was accused of intellectual arrogance by the magicians of ceremonial magic: its megalomaniac world explanation was something different from the concentration on man as subject of occult practice in the Golden Dawn. Other differences may lurk in the background (as a male-female opposition in its respective leader figures).

\section{Conclusion}

A recent study, The Science of Religion in Britain, 1860-1915, by Marjorie WheelerBarclay, concentrates on six names that are characterized by her as essential and foundational personalities for what was to become Religious Studies. These are Friedrich Max Müller, Edward Burnett Tylor, Andrew Lang, William Robertson Smith, James George Frazer, and Jane Ellen Harrison. Unfortunately, WheelerBarclay pays little attention to occult and "fringe science" connections. ${ }^{108}$ In a similar vein Udo Tworuschka in his concise Einführung in die Geschichte der Religionswissenschaft ${ }^{109}$ mentions these and some other British examples as ancestors of the science of religion. A fuller analysis would have to consider other British writers often little known today but also searching for a basic unity of religions, conversant with Lang, Frazer, Tylor and others, and deeply interested in occultism as well. Examples would be William Scott-Elliot (1849-1919), the Tenth Laird of Arkleton, who (using the pen name William Williamson) e.g. wrote The Great Law. A Study of Religious Origins and of the Unity Underlying them. ${ }^{110}$ Other persons deserving closer attention are Madame

107 S. L. MacGregor Mathers, Astral Projection, Ritual Magic and Alchemy: Golden Dawn Material by S. L. MacGregor Mathers and Others (Rochester, Vermont: Destiny Books, 1987), 148.

108 But cf. Marjorie Wheeler-Barclay, The Science of Religion in Britain, 1860-1915 (Charlottesville: University of Virginia Press, 2010), 124-129 on Lang's study of the comparative folklore of ghosts.

109 Udo Tworuschka, Einführung in die Geschichte der Religionswissenschaft (Darmstadt: WB, 2015).

110 William Williamson, The Great Law: A Study of Religious Origins and of the Unity Underlying them (London: Longmans, Green \& Co., 1899). 
Blavatsky's last secretary, George Robert Stow Mead (rarely written George Robert Stowe Mead, mostly abbreviated G.R.S. Mead, 1863-1933), a translator of gnostic and hermetic literature, Isabel Cooper-Oakley (1854-1914), India-born author of many books in the field, Alexander Wilder (1823-1908), the actual author of some parts of Blavatsky's Isis Unveiled, Walter Yeeling Evans-Wentz (1878-1965), today mainly remembered for his later books on Tibetan Buddhism, but initially a scholar of Celtic religion in a comparative perspective, and also a theosophist, and the egyptologist E. A. Wallis Budge, a firm believer in a number of occult concepts. (All these are discussed in the fuller version of this study).

Occultism by its mere existence may have been a kind of catalyst. A catalyst in chemistry of course is a substance that causes or accelerates a chemical reaction without itself being affected, or changing the chemical composition of the substance it influences. Occultism and in particular Theosophy might have contributed to comparative religion by its very existence, not only by tangible ideas taken over. As a competing factor in Victorian society it forced to think about the unity of religions, about east and west, about the magical, arcane and esoteric side of religion. Both movements (comparative religion and occultism) share what today we perhaps might call an essentialist outlook on religion, but this is here a minor point.

We may mention one last aspect the early science of religion and the occult discourse of the late nineteenth century have in common. This is their bland, almost naïve optimism (though it can be combined with some cautious critical remarks about possible changes in the near future). We quote only one specimen:

It is our happiness to live in one of those eventful periods of intellectual and moral history, when the oft-closed gates of discovery and reform stand open at their widest. How long these good days may last, we cannot tell. It may be that the increasing power and range of the scientific method, with its stringency of argument and constant check of fact, may start the world on a more steady and continuous course of progress than it has moved on heretofore. But if history is to repeat itself according to precedent, we must look forward to stiffer duller ages of traditionalists and commentators, when the great thinkers of our time will be appealed to as authorities by men who slavishly accept their tenets, yet cannot or dare not follow their methods through better evidence to higher ends. In either case, it is for those among us whose minds are set on the advancement of civilization, to make the most of present opportunities [. . . ]. It is a harsher, and at times even painful, office of ethnography to expose the remains of crude old culture which have passed into harmful superstition, and to mark these out for destruction. Yet this work, if less genial, is not less urgently needful for the good of mankind. Thus, active at once in aiding progress and in removing hindrance, the science of culture is essentially a reformer's science. ${ }^{111}$

111 Tylor, Primitive Culture, vol. 1, 452-453. 
What does this prove? Eventually we will get a history of the Victorian and Edwardian encounter with religion as the "Other", as something strange and perhaps wild, but also as something to be researched with restraint and method. This might have been an aspect of the background that made the science of religion what it is: a field of unending fascination and discovery. Its sidetracks and hidden undergrounds in occult discourses, and the people behind it, are certainly worthy of further investigation, and may yet yield a number of surprises.

\section{Bibliography}

Ackerman, Robert. J. G. Frazer: His Life and Work. Cambridge: Cambridge University Press, 1987.

—. Selected Letters of Sir J.G. Frazer. Oxford: Oxford University Press, 2005.

Baird, Alexander T. Richard Hodgson: The Story of a Psychical Researcher and his Times. London: Psychical Press, 1949.

Barker, A. Trevor, ed. The Letters of H. P. Blavatsky to A. P. Sinnett, and other Miscellaneous Letters. Transcribed (. . .) by A. T. Barker. 1925. Reprinted Pasadena.: Theosophical University Press, 1973.

Blavatsky, Helena Petrovna. Isis Unveiled: A Master-key to the Mysteries of Ancient and Modern Science and Theology, 2 vols. New York: J. W. Bouton/London: Bernard Quaritch, 1877. New edition, edited by Boris de Zirkoff. Wheaton, II. a.o.: Theosophical Publishing House, 1994. Reprint from 1972.

- The Secret Doctrine: The Synthesis of Science, Religion, and Philosophy. 2 vols. New edition with index volume, edited by Boris de Zirkoff. Adyar, Madras, India: Theosophical Publishing House, 1993. First published 1888 by The Theosophical Publishing Company (London).

- Collected Writings, edited by Boris de Zirkoff. 15 vols. Wheaton/Adyar: Theosophical Publishing House, 1966-1991.

- The People of the Blue Mountains. Wheaton: Theosophical Press, 1930.

Bosch, Lourens van den. Friedrich Max Müller: A Life Devoted to the Humanities. Studies in the History of Religions 94. Leiden: Brill, 2002.

Britten, Emma Hardinge. The Faiths, Facts, and Frauds of Religious History. Melbourne: George Robertson, 1879.

- Nineteenth Century Miracles: or, Spirits and their Work in every Country of the Earth; A Complete Historical Compendium of the Great Movement Known as "Modern Spiritualism". Manchester: William Britten, 1883.

Caithness, Marie Countess of, Duchess de Pomár. The Mystery of the Ages Contained in the Secret Doctrine of all the Ages. 2nd ed. London: Wallace, 1887.

Clodd, Edward. The Childhood of Religions: Embracing a Simple Account of the Birth and Growth of Myths and Legends. London: Henry S. King, 1875.

-. Myths and Dreams. London: Chatto \& Windus, 1891.

- Tom Tit Tot: An Essay on Savage Philosophy in Folk-tale. London: Duckworth, 1898.

- The Question: A Brief History and Examination of Modern Spiritualism. London: Richards, 1917. 
Dorson, Richard Mercer. The British Folklorists: A History. London: Routledge \& Kegan, 1968. Downie, R. Angus. James George Frazer: The Portrait of a Scholar. London: Watts, 1940. Fiske, John. Myths and Myth-Makers: Old Tales and Superstitions Interpreted by Comparative Mythology. Boston/New York: Houghton, Mifflin and Company; Cambridge: The Riverside Press, 1902. First published in 1873 by Trübner \& Co. (London).

Franklin, J. Jeffrey. Spirit Matters: Occult Beliefs, Alternative Religions, and the Crisis of Faith in Victorian Britain. Ithaca/London: Cornell University Press, 2018.

Frazer, James George. The Golden Bough: A Study in Comparative Religion. 2 vols. London: Macmillan, 1890.

- The Golden Bough: A Study in Magic and Religion. 3rd ed. 13 vols. London: Macmillan, 1906-1937.

Frenschkowski, Marco. “Charles Godfrey Leland (1824-1903) und die Ursprünge der WiccaReligion." In: Faszination des Okkulten: Diskurse zum Übersinnlichen, edited by Wolfgang Müller-Funk and Christa A. Tuczay, 273-335. Tübingen: Francke, 2008.

__. "Wellhausen, Julius." In: Biographisch-Bibliographisches Kirchen Lexikon 13, edited by Friedrich W. Bautz, 716-727. Hamm: Bautz, 1998.

—. Geheimbünde: Eine kulturgeschichtliche Analyse. 6th ed. Wiesbaden: Marixverlag, 2007, 2016.

—_. "Theosophy, Magic and the Literary Imagination: Remarks on H. P. Blavatsky." In: Fictional Practice: Magic, Narration and the Power of Imagination edited by BerndChristian Otto. Leiden: Brill, 2021.

__. "Fortunatae Insulae: Die Identifikation mythischer Inseln mit realen geographischen Gegebenheiten in der griechischen und römischen Antike.” In: Konstruktionen mediterraner Insularitäten, edited by Reinhard von Bendemann, Annette Gerstenberg, Nikolas Jaspert, and Sebastian Kolditz, 43-73. Paderborn: Fink/Schöningh, 2016.

__. "Heinrich Cornelius Agrippa von Nettesheim und seine „Okkulte Philosophie“: ein Vorwort.” In: Heinrich Cornelius Agrippa von Nettesheim: Die magischen Werke und weitere Renaissancetraktate, edited and introduced by Marco Frenschkowski, 23-45. Wiesbaden: Marixverlag, 2008.

Gomme, George Laurence. Folklore as an Historical Science. London: Methuen, 1908. Green, Roger Lancelyn. Andrew Lang: A Critical Biography. Leicester: Ward, 1946.

Hanegraaff, Wouter. "The Emergence of the Academic Science of Magic: The Occult Philosophy in Tylor and Frazer." In: Religion in the Making: The Emergence of the Sciences of Religion, edited by Arie L. Moldedijk and Peter Pels, 253-275. Leiden: Brill, 1998.

- Esotericism and the Academy: Rejected Knowledge in Western Culture. Cambridge: Cambridge University Press, 2012.

Harnack, Adolf von. "Gedanken über Wissenschaft und Leben (1905).” In: Wissenschaftspolitische Reden und Aufsätze, edited by Bernhard Fabian, 222-227. Hildesheim: Olms-Weidmann, 2001).

Harris, Philip S., Vicente Hao Chin, and Richard Williams Brooks, eds. Theosophical Encyclopedia. Quezon City, Philippines: Theosophical Publishing House, 2006.

Harrison, Vernon. H. P. Blavatsky and the SPR: An Examination of the Hodgson Report of 1885. Pasadena.: Theosophical University Press, 1997.

Hartland, Edwin Sidney. The Science of Fairy Tales: An Inquiry into Fairy Mythology. London: Scott, 1891.

- Perseus: A Study of Tradition in Story, Custom and Belief. 3 vols. London: David Nutt, 1894-1896 
- Folklore: What Is It and What Is the Good of It?. London: David Nutt, 1899.

- Primitive Paternity: The Myth of Supernatural Birth in Relation to the History of the Family. 2 vols. London: David Nutt, 1909-1910.

- . "The Relations of Religion and Magic." In: Ritual and Belief: Studies in the History of Religion, edited by Edwin S. Hartland, 26-160. New York: Charles Scribner's Sons, 1914.

_- C. Staniland Wake, Henry B. Wheatley, and G.L. Gomme. "Folk-Lore Terminology." The Folk-Lore Journal 2, no. 11 (Nov. 1884): 340-348

Hodgson, Richard. "An Account of Personal Investigations in India, and Discussion of the Authorship of the "Koot Hoomi” Letters:" Together with: Report of The Committee Appointed to Investigate Phenomena Connected with the Theosophical Society. Proceedings of the Society for Psychical Research 3 (1885): 201-400

Huxley, Thomas. Collected Essays. 9 vols. London: Macmillan and Co., 1893-1895. Reprint Hildesheim: Olms, 1970.

Jordan, Louis Henry. Comparative Religion: Its Adjuncts and Allies. London: Oxford University Press, 1915.

- Comparative Religion: Its Genesis and Growth. Edinburgh: T. \& T. Clark, 1905.

Judge, William Q. “Letters of H. P. Blavatsky.” Part 4. The Path (Dec. 1894-Dec. 1895).

Kingsford, Anna, and Maitland, Edward. The Perfect Way; or, the Finding of Christ. 7th ed. Macoy: Publishing \& Masonic Supply Company 1919. First published 1882 by Field \& Tuer (London)

Klatt, Norbert. Der Nachlaß von Wilhelm Hübbe-Schleiden in der Niedersächsischen Staatsund Universitätsbibliothek Göttingen: Verzeichnis der Materialien und Korrespondenten mit bio-bibliographischen Angaben. Göttingen: Klatt, 1996.

Knapp, Krister Dylan. William James: Psychical Research and the Challenge of Modernity. Chapel Hill: University of North Carolina Press, 2017.

Lang, Andrew. Method in the Study of Totemism. Glasgow: Maclehose, 1911.

—. Magic and Religion. London: Longmans, Green, and Co., 1901.

- The Making of Religion. London: Longmans, Green, and Co., ${ }^{2} 1900$.

- Cock Lane and Common-Sense. New ed. Cambridge: Cambridge University Press, 1896.

- Kirk's Secret Commonwealth: The Secret Commonwealth of Elves, Fauns \& Fairies; A Study in Folk-lore \& Psychical Research. Text by R. Kirk, M.A., Minister of Aberfoyle, A.D. 1691, commented by A. Lang. London: Nutt, 1893.

-. Modern Mythology. London: Longmans, Green, and Co., 1897.

-. Myth, Ritual and Religion. 2 vols. new impr. London: Longmans, Green \& Co. 1906. First publuished 1887 by Longmans, Green \& Co. (London).

- The Edinburgh Critical Edition of the Selected Writings. 2 vols. ed. by Teverson, Andrew; Warwick, Alexandra; Wilson, Leigh. Edinburgh: Edinburgh University Press 2015.

Larsen, Timothy. The Slain God: Anthropologists and the Christian Faith. Oxford: Oxford University Press, 2014.

Lubelsky, Isaac. "Friedrich Max Müller vs. Madame Blavatsky: A Chronicle of a (very) Strange Relationship." In: Theosophical Appropriations: Esotericism, Kabbalah, and the Transformation of Traditions, edited by Julie Chajes and Boaz Huss, 73-91. Beer Sheva: Ben-Gurion University of the Negev Press, 2016.

MacGregor Mathers, S. L. Astral Projection, Ritual Magic, and Alchemy. Golden Dawn Material by S. L. MacGregor Mathers and Others, edited and introduced by Francis King. Rochester, Vermont: Destiny Books, 1987. 
Marchand, Suzanne L. German Orientalism in the Age of Empire: Religion, Race, and Scholarship. German Historical Institute: Washington, D.C.; Cambridge: Cambridge University Press, 2009.

Müller, Friedrich Max. Theosophy or Psychological Religion. London: Longmans, Green and Co. 1893.

. Introduction to the Science of Religion: Four Lectures Delivered at the Royal Institution: with two Essays on False Analogies, and the Philosophy of Mythology. New ed. London and Bombay: Longmans, Green and Co., 1893. First published 1873 by Longmans, Green and Co. (London).

—. The Upanishads. Part 1. The Sacred Books of the East 1. Oxford: The Clarendon Press 1879.

- Chips from a German Workshop. 5 vols. New ed. New York: Charles Scribner's Sons, 1900-1907.

—. Aus meinem Leben: Fragmente zu einer Selbstbiographie. Gotha: Perthes, 1902.

Müller, Georgina Adelaide, ed. The Life and Letters of the Right Honourable Friedrich Max Müller. 2 vols. New York: Longmans, 1902.

Murphy, Gardner, and Robert O. Ballou. William James on Psychical Research. London: Chatto \& Windus, 1961.

Nord, Deborah Epstein. Gypsies and the British Imagination, 1807-1930. New York: Columbia University Press, 2006.

Olcott, Henry Steel. Old Diary Leaves. 6 vols. New York: G.P. Putnam's Sons, 1895-1935. Reprint Adyar, Madras: Theosophical Publishing House, 1974-1975. First published 1892-1906: in: The Theosophist.

Owen, Alex. The Place of Enchantment: British Occultism and the Culture of the Modern. Chicago: Chicago University Press, 2004.

Podmore, Frank, and Edmund Gurney. Phantasms of the Living. 2 vols. London: Trübner \& Co., 1886.

Sharpe, Eric J. Comparative Religion: A History. 2nd. ed. La Salle, Illinois: Open Court, 1986.

Sinnett, Alfred Percy. The Early Days of Theosophy in Europe. London: Theosophical Publ. House, 1922.

Smith, Jonathan Zittell. "The Glory, Jest and Riddle: James George Frazer and The Golden Bough.” PhD diss., University of Yale, 1969.

Smith, William Robertson. Lectures on the Religion of the Semites: Fundamental Institutions. Third edition, introduced and additional notes by Stanley A. Cook. London: Black, 1927. First published 1889 1st Ser. by Adam \& Charles Black (London).

Stocking, George W. “Animism in Theory and Practice: E. B. Tylor's Unpublished Notes on Spiritualism." Man 6 (1971): 88-104

Thévoz, Seth Alexander. Club Government: How the Early Victorian World was Ruled from London Clubs. London: I.B. Tauris, 2018.

Tillett, Gregory John. The Elder Brother: A Biography of Charles Webster Leadbeater. London: Routledge \& Kegan Paul, 1982.

__. "Charles Webster Leadbeater 1854-1934: A Biographical Study.” PhD. diss., University of Sidney 1986.

Tworuschka, Udo. Einführung in die Geschichte der Religionswissenschaft. Darmstadt: Wissenschaftliche Buchgesellschaft, 2015. 
Tylor, Edward Burnett. Primitive Culture: Researches into the Development of Mythology, Philosophy, Religion, Language, Art, and Custom. 2 vols. 6th ed. London: John Murray, 1920.

_- "Images and Names." In: Researches into the Early History of Mankind and the Development of Civilization, 106-149. New edition London: Routledge, 1994.

__. "Exhibition of Charms and Amulets," In The International Folk-Lore Congress 1892: Papers and Transactions, edited by Joseph Jacobs and Alfred Nutt. London: David Nutt, 1892.

Varto, Emily, ed. Brill's Companion to Classics and Early Anthropology. Brill's Companions to Classical Reception 16. Leiden: Brill, 2018.

Webb, James. Die Flucht vor der Vernunft: Politik, Kultur und Okkultismus im 19. Jahrhundert, edited by Marco Frenschkowski and Michael Siefener, translated by Michael Siefener. Wiesbaden: Marixverlag, 2009.

Wheeler-Barclay, Marjorie. The Science of Religion in Britain, 1860-1915. Charlottesville: University of Virginia Press, 2010.

Williamson, William. The Great Law: A Study of Religious Origins and of the Unity Underlying them. London: Longmans, Green, \& Co., 1899. 